Gut, 1984, 25, 381-385

\title{
Peptide histidine isoleucine: a secretagogue in human jejunum
}

\author{
A A ANAGNOSTIDES. N D CHRISTOFIDES. K TATEMOTO. \\ V S CHADWICK. AND S R BLOOM
}

\begin{abstract}
From the Department of Medicine, Roval Postgraduate Medical School, Hammersmith Hospital, London; and Department of Biochemistry, Nobel Medical Institute, Karolinska Institute, S-1041, Stockholm, Sweden.
\end{abstract}

Summary Peptide histidine isoleucine (PHI) is a newly discovered peptide from porcine intestine, which has sequence homologies with VIP. an established intestinal secretagogue. To study the effects of PHI in human jejunum, natural porcine PHI was infused intravenously at $10 \cdot 7 \pm 1.7 \mathrm{pmol} / \mathrm{kg} / \mathrm{min}$ (mean $\pm \mathrm{SEM}$ ) in normal volunteers during steady state perfusion of the jejunum with an isotonic bicarbonate-electrolyte solution. Plasma PHI concentrations rose to $279 \pm 26 \mathrm{pmol} / \mathrm{l}$ (mean $\pm \mathrm{SEM}$ ) in the first 20 minutes of the infusion reaching $417 \pm 45$ at 40 minutes. At these concentrations PHI induced a net secretion of chloride and sodium and either decreased net absorption or increased net secretion of fluid and potassium, while bicarbonate transport remained unaffected. Peptide histidine isoleucine is a potent jejunal secretagogue in man.

Peptide histidine isoleucine has recently been isolated as a heptacosapeptide from porcine small intestine. $^{12}$ This peptide $(\mathrm{P})$ has an $\mathrm{N}$-terminal histidine $(\mathrm{H})$ and $\mathrm{C}$-terminal isoleucine (I) amide and therefore has been given the acronym PHI. Remarkable sequence homologies exist between PHI and VIP. secretin, glucagon, and GIP. indicating that PHI belongs to this family of peptides. $^{2}$

The effects of PHI have been studied in a variety of species. It has been shown to stimulate pancreatic juice $^{3}$ and amylase secretion ${ }^{4}$, and to be potent stimulus for cyclic-AMP production in a variety of tissues - namely, fat cells, gastric and intestinal epithelial cells, ${ }^{5}$ and pancreatic acinar cells though to have little effect on blood flow. ' It is reported to interact with a class of receptors which have a high affinity for VIP and a low affinity for secretin. ${ }^{4}$

We have recently developed a sensitive radioimmunoassay for PHI which shows no crossreactivity with the other members of the glucagonsecretin family. In animal and human intestine PHI is distributed along the entire length of the gastrointestinal tract with highest concentrations in the colon. It is found in the submucosa of the gut and is present in brain and neural tissues ${ }^{7}$ suggesting a

Address for correspondence: Prof S R Bloom. Department of Medicine. Royal Postgraduate Medical School. Hammersmith Hospital. Ducane Road. l.ondon WII OHS

Received for publication 6 July 198.3 neurotransmitter or neuromodulator role. More recently we have shown that infusion of $\mathrm{PHI}$ in pigs and rats induced secretion of intestinal fluid. ${ }^{8}$ "Its effect on the human jejunum was investigated as an essential preliminary step before studies of its possible role in human diarrhoeal disorders.

\section{Methods}

Studies were performed in six healthy volunteers (three men, three women), mean age 26.5 years (range 23-35 years). Informed written consent was obtained and the studies were approved by the Hammersmith Hospital and Royal Postgraduate Medical School Research Ethics Committee.

After an overnight fast a triple lumen perfusion tube with a mercury bag at the tip was passed into the jejunum under fluoroscopic control so that the infusion port was at the ligament of Treitz, the proximal sampling site at $10 \mathrm{~cm}$ distally and the distal sampling site at $40 \mathrm{~cm}(10 \mathrm{~cm}$ mixing segment and $30 \mathrm{~cm}$ test segment). The jejunum was perfused at $10 \mathrm{ml} / \mathrm{min}$ (by a peristaltic pump) with an isotonic bicarbonate-electrolyte solution $\left(37^{\circ} \mathrm{C}\right)$ containing $\mathrm{Na}^{+} 135, \mathrm{~K}^{+} 5, \mathrm{Cl}^{-} 110, \mathrm{HCO}_{3}^{-} 30(\mathrm{mmol} / \mathrm{l})$ and polyethylene glycol (PEG) $4000 \quad 0.5 \mathrm{~g} / \mathrm{l}$ with ${ }^{1+} \mathrm{C}$ PEG $40005 \mu \mathrm{Ci} / 1$, as non-absorbable marker. The perfusate was continually gassed with $5 \% \mathrm{CO}_{2}$ and $95 \% \mathrm{O}_{2}$. After a 40 minute equilibration period and a 40 minute first control period, pure natural porcine 
PHI in saline with $1 \%$ human serum albumin, was infused intravenously at a nominal dose of 10 $\mathrm{pmol} / \mathrm{kg} / \mathrm{min}$ for either 40 (six subjects) or 60 minutes (three subjects), followed by a 40 minute final control period. Limited supplies of pure PHI for human studies precluded the use of 60 minute infusions in all subjects. Regular aspiration from the two sampling sites was performed by hand, using 20 $\mathrm{ml}$ plastic syringes to obtain $4 \mathrm{ml}$ from each site in each 10 minute collection period. Aspirates were collected on ice and samples for bicarbonate assay immediately covered with paraffin oil. Blood samples were collected in heparinised trasylol tubes $(400 \mathrm{KIUm})$ at 10 minute intervals, centrifuged immediately and plasma stored at $-20^{\circ} \mathrm{C}$ for subsequent PHI assays.

\section{LABORATORY MEASUREMENTS \\ Intestinal samples}

These were assayed the same day for ${ }^{14} \mathrm{C}$-PEG 4000 using a Packard Tricarb 2660 liquid scintillation counter with external standard quench correction. Sodium and potassium were measured using a Corning 40S flame photometer, chloride using an automatic Bucheler-Cotlove chloridometer, Bucheler Instruments Inc, Fort Lee, NJ, USA, and bicarbonate by a Technicon auto-analyser method.

\section{Radioimmunoassay}

The development and validation of the radioimmunoassay for PHI has previously been reported. ${ }^{7}$ The coefficient of variation between assays was $15 \%$ and within assays $9 \%$. Changes of $10 \mathrm{pmol} / \mathrm{l}$ plasma could be detected with $95 \%$ confidence at the most sensitive point of the curve that is, the assay could detect changes of $2 \mathrm{fmol}$ per tube.

\section{Calculation and statistics}

Net absorption or secretion of fluid $(\mu \mathrm{l})$ and electrolytes $(\mu \mathrm{mol}) / \mathrm{cm} / 10 \mathrm{~min}$ were calculated using standard equations. Mean \pm SEM values were then determined for sequential 20 minute experimental periods. The significance between periods was assessed by the paired Student's $t$ test.

\section{Results}

PLASMA PHI CONCENTRATIONS

Measured infusion rates of natural porcine $\mathrm{PHI}$ were $10.7 \pm 1.7 \mathrm{pmol} / \mathrm{kg} / \mathrm{min}($ mean \pm SEM). Table 1 shows plasma PHI concentrations before, during and after PHI infusion. Peptide histidine isoleucine was undetectable in the plasma in the first control period (detection limit $10 \mathrm{pmol} / \mathrm{l}$ ), rose to $279 \pm 26$ $\mathrm{pmol} / \mathrm{l}$ in the first 20 minutes of infusion and reached $417 \pm 45 \mathrm{pmol} / \mathrm{l}$ at 40 minutes and $500 \pm 144$ at 60 minutes $(n=3)$. After discontinuation of infusion PHI concentrations returned to $105 \pm 25$ in subjects receiving PHI infusion for 40 minutes and $123 \pm 35$ in subjects receiving $\mathrm{PHI}$ infusion for 60 minutes.

\section{SYSTEMIC EFFECTS OF PHI}

No significant untoward effects were observed though transient facial flushing was observed in one subject towards the end of the infusion. No changes in blood pressure or pulse rate occurred.

\section{EFFECT OF PHI ON FLUID AND ELECTROLYTE MOVEMENTS}

Table 2 shows the effects of PHI infusion on fluid and electrolyte movement in the jejunal test segment. Net absorption of fluid and electrolytes was observed in all subjects in the first control period. Peptide histidine isoleucine infusion induced inhibition of fluid absorption in the first 40 minute period $(n=6)$ and fluid secretion $(n=3)$ between 40 and 60 minutes while net sodium and chloride secretion (Figure) was observed between 20 and 40 minutes (in five of six subjects). Potassium absorption was inhibited in all subjects, and no effect on bicarbonate transport were observed. ${ }^{14} \mathrm{C}$-PEG concentrations in fluid entering the test segment were $1547 \pm 187$ (SEM) dpm/200 $\mu$ l in the control period and $1625 \pm 281 \mathrm{dpm} / 200 \mu \mathrm{l}$ during PHI infusion (see discussion).

The composition of the fluid entering the test segment in control and PHI infusion periods is shown in Table 3.

Table 1 Peptide histidine isoleucine plasma concentrations before, during and after PHI infusion (pmolll)

\begin{tabular}{|c|c|c|c|c|c|c|}
\hline \multicolumn{2}{|c|}{ First control period } & \multicolumn{3}{|c|}{ PHI infusion period } & \multicolumn{2}{|c|}{$\begin{array}{l}\text { Final control period } \\
\text { (time after cessation of } P H I)\end{array}$} \\
\hline $\begin{array}{l}-40^{\prime}(\mathrm{n}=6) \\
\text { undetectable }\end{array}$ & $\begin{array}{l}-20^{\prime}(n=6) \\
\text { undetectable }\end{array}$ & $\begin{array}{l}+20^{\prime}(n=6) \\
279 \pm 26\end{array}$ & $\begin{array}{l}+40^{\prime}(n=6) \\
417 \pm 45\end{array}$ & $\begin{array}{l}+60^{\prime}(n=3) \\
500 \pm 144\end{array}$ & $\begin{array}{l}+20^{\prime} \\
\text { A } 105 \pm 25 \\
\text { B } 123 \pm 45\end{array}$ & $\begin{array}{l}+40^{\prime} \\
\text { undetectable } \\
\text { undetectable }\end{array}$ \\
\hline
\end{tabular}

Values are mean $\pm \mathrm{SEM}$. Detection limit $10 \mathrm{pmol} / \mathrm{l}$.

A subjects receiving $40^{\prime} \mathrm{PHI}$ infusion $(n=3)$.

B subjects receiving $60^{\prime} \mathrm{PHI}$ infusion $(n=3)$. 
Table 2 Effect of PHI infusion on jejunum

\begin{tabular}{|c|c|c|c|c|c|c|c|}
\hline & \multicolumn{3}{|c|}{ First control period } & \multicolumn{2}{|c|}{ PHI infusion period } & \multicolumn{2}{|c|}{$\begin{array}{l}\text { Final control period } \\
\text { (time after cessation of } \mathrm{PHI} \text { ) }\end{array}$} \\
\hline & -40 & -20 & +20 & +40 & $+60(n=3)$ & +20 & +40 \\
\hline $\begin{array}{l}\text { Water } \\
(\mathrm{ml} / \mathrm{cm} / 10 \mathrm{~min})\end{array}$ & $-2 \cdot 0 \pm 0 \cdot 6$ & $-1 \cdot 5 \pm 0 \cdot 3$ & $-0 \cdot 41 \pm 0 \cdot 2^{*}$ & $-0 \cdot 09 \pm 0 \cdot 2^{*}$ & $+0 \cdot 39 \pm 0 \cdot 3$ & $-1 \cdot 0 \pm 0 \cdot 3$ & $-1 \cdot 3 \pm 0 \cdot 3$ \\
\hline $\begin{array}{l}\text { Chloride } \\
(\mu \mathrm{mol} / \mathrm{cm} / 10 \mathrm{~min})\end{array}$ & $-103 \cdot 0 \pm 15 \cdot 0$ & $-105 \cdot 0 \pm 13 \cdot 0$ & $-0 \cdot 8 \pm 12 \cdot 3 \dagger$ & $+27 \cdot 5 \pm 2 \cdot(04 \dagger$ & $+101 \cdot 0 \pm 18 \cdot 0$ & $-33 \cdot 4 \pm 16 \cdot 3$ & $-105 \cdot 0 \pm 30 \cdot 8$ \\
\hline $\begin{array}{l}\text { Sodium } \\
(\mu \mathrm{mol} / \mathrm{cm} / 10 \mathrm{~min})\end{array}$ & $-117 \cdot 0 \pm 23 \cdot 0$ & $-92 \cdot 0 \pm 23 \cdot 0$ & $-28 \cdot 3 \pm 25 \cdot 8^{*}$ & $+18 \cdot 3 \pm 25 \cdot 8^{*}$ & $+72 \cdot 0 \pm 46 \cdot 0$ & $-73 \cdot 7 \pm 11 \cdot 0$ & $-94 \cdot 0 \pm 21 \cdot 0$ \\
\hline $\begin{array}{l}\text { Potassium } \\
(\mu \mathrm{mol} / \mathrm{cm} / 10 \mathrm{~min})\end{array}$ & $-12 \cdot 0 \pm 2 \cdot 5$ & $-11 \cdot 0 \pm 2 \cdot 2$ & $-5 \cdot 7 \pm 0 \cdot 9^{*}$ & $-4 \cdot 4 \pm 1 \cdot 3^{*}$ & $-0 \cdot 9 \pm 2 \cdot 0$ & $-7 \cdot 5 \pm 1 \cdot 6$ & $-12 \cdot 2 \pm 3 \cdot 26$ \\
\hline $\begin{array}{l}\text { Bicarbonate } \\
(\mu \mathrm{mol} / \mathrm{cm} / 10 \mathrm{~min})\end{array}$ & $-21 \cdot 0 \pm 5 \cdot 5$ & $-21 \cdot 0 \pm 5 \cdot 3$ & $-25 \cdot 3 \pm 6 \cdot 7$ & $-49 \cdot 6 \pm 21 \cdot 5$ & $+6 \cdot 6 \pm 12 \cdot 0$ & $-49 \cdot 5 \pm 10 \cdot 0$ & $-53 \cdot 0 \pm 83 \cdot 0$ \\
\hline
\end{tabular}

Negative signs indicate absorption and positive signs secretion.

${ }^{*} \mathrm{p}<0 \cdot 05 .+\mathrm{p}<0 \cdot 005$ (control periods $v s \mathrm{PHI}$ infusion period).

Numbers are mean \pm SEM of six observations.

\section{Discussion}

Intravenous infusion of $\mathrm{PHI}$ at doses achieving plasma concentrations in the range $400-500 \mathrm{pmol} / \mathrm{l}$ induced net secretion of sodium and chloride and either secretion or a reduction in net absorption of fluid and potassium in human jejunum. These

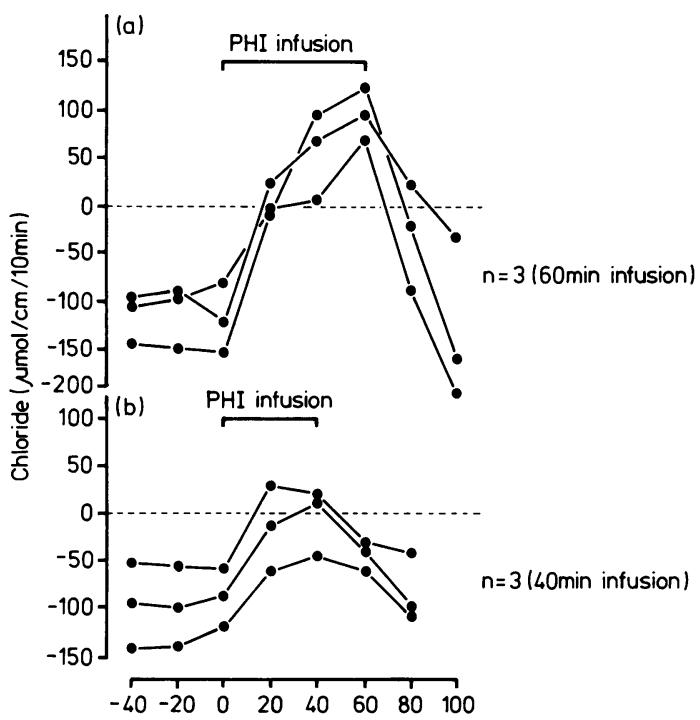

Figure Effects of PHI infusion on net chloride movements in six subjects. Upper panel shows results from three subjects receiving PHI over 60 minutes and lower panel shows results from three subjects receiving PHI over 40 minutes. Net chloride secretion was observed in five out of six subjects (negative values denote absorption, positive values denote secretion). observations confirm that $\mathrm{PHI}$ is a potent secretagogue in human small intestine. With triple lumen perfusion techniques, the possibility exists of contamination of the test segment with digestive secretions from above. In these studies the volume of fluid entering the test segment, calculated from ${ }^{14} \mathrm{C}$-PEG concentrations, was marginally less during PHI infusion than during the control period. In separate studies (unpublished) we have shown that PHI has no effect on pancreatic, trypsin, and bicarbonate secretion in man in contrast with reports from animal studies, ${ }^{3}$ but reduces bile acid output into the duodenum. It is not likely therefore that entry of digestive secretions from above could be responsible even in part for the secretory effects and further studies in rat and porcine intestine ${ }^{89}$ using closed loops of small intestine confirm that $\mathrm{PHI}$ is a potent secretagogue.

Table 3 Composition of the fluid entering the test segment in control and PHI infusion periods

\begin{tabular}{lccc}
\hline & $\begin{array}{l}\text { Initial control } \\
\text { period }\end{array}$ & PHI infusion & $\begin{array}{l}\text { Final control } \\
\text { period }\end{array}$ \\
\hline $\begin{array}{l}\text { Fluid } \\
(\mathrm{ml} / 10 \mathrm{~min})\end{array}$ & $25 \cdot 7 \pm 7 \cdot 6$ & $27 \cdot 3 \pm 7 \cdot 2$ & $27 \cdot 2 \pm 11 \cdot 0$ \\
$\begin{array}{l}{ }^{14} \mathrm{C}-\mathrm{PEG} 4000 \\
(\mathrm{dpm} / 200 \mu \mathrm{l})\end{array}$ & $1547 \cdot 0 \pm 187 \cdot 0$ & $1625 \cdot 0 \pm 281 \cdot 0$ & $1586 \cdot 0 \pm 235 \cdot 0$ \\
$\begin{array}{l}\mathrm{HCO}_{3}^{-} \\
\left(\mathrm{mmol}^{-} / 10 \mathrm{~min}\right)\end{array}$ & $2 \cdot 3 \pm 0 \cdot 5$ & $2 \cdot 5 \pm 0 \cdot 6$ & $3 \cdot 0 \pm 0 \cdot 6$ \\
$\begin{array}{l}\mathrm{Na}^{+} \\
(\mathrm{mmol} / 10 \mathrm{~min})\end{array}$ & $12 \cdot 0 \pm 1 \cdot 6$ & $11 \cdot 8 \pm 1 \cdot 5$ & $11 \cdot 9 \pm 1 \cdot 4$ \\
$\begin{array}{l}\mathrm{Bile} \mathrm{acid} \\
(\mu \mathrm{mol} / 10 \mathrm{~min})\end{array}$ & $299 \cdot 0 \pm 90 \cdot 0$ & $191 \cdot 0 \pm 33 \cdot 0^{*}$ & $305 \cdot 0 \pm 98 \cdot 0$ \\
\hline
\end{tabular}

Numbers are mean \pm SEM of six observations.

${ }^{*} \mathrm{p}<0.01$ control $v s \mathrm{PHI}$ infusion periods. 
Peptide histidine isoleucine shows considerable sequence homology with VIP and GIP both of which are established secretagogues in man, ${ }^{10} 11$ while it also has structural similarities to glucagon and secretin which are also intestinal secretagogues. ${ }^{12-15}$ In receptor studies with pancreatic acinar cells $\mathrm{PHI}$ appeared to interact with receptors having high affinity for VIP and low affinity for secretin ${ }^{4}$ so that its functional activity, which closely resembles that of VIP, might relate to that part of the molecule which binds to such receptors.

Like VIP, PHI activates adenyl cyclase in a variety of tissues including intestinal epithelial cells, ${ }^{5}$ however, the potential for activating the adenyl-cyclase-cAMP system does not necessarily imply a cyclic-AMP mediated secretory mechanism. For example, VIP may induce intestinal secretion without measureable changes in mucosal cAMP concentrations in animals ${ }^{16}$ or man, ${ }^{17}$ and plasma concentrations which produce intestinal fluid secretion are well below those capable of activating adenylate cyclase in in vitro systems. ${ }^{18-20}$ VIP may affect fluid transport via alterations in mucosal blood flow, ${ }^{21} 22$ a mechanism apparently not open to PHI. ${ }^{6}$ The as yet unresolved question about the mode of action of VIP may well apply to PHI in vivo.

Most patients with the Verner-Morrison syndrome who have pancreatic apudomas or ganglioneuromas have high circulating concentrations of VIP ${ }^{23-25}$ and it is generally believed that this peptide mediates the intestinal secretion of water and electrolytes which account for the secretory diarrhoea. Peptide histidine isoleucine appears to be elaborated by pancreatic or neuroendocrine tumours in those patients who have high circulating VIP concentrations. ${ }^{26}$ The possibility that PHI may be raised in patients who are said to have the pseudo Verner-Morrison syndrome, ${ }^{25}$ (with normal VIP concentrations), warrants investigation.

Our current studies do not provide information about the relative secretory bioactivity of PHI and VIP. In human studies Krejs showed intestinal secretion in response to VIP infusions with plasma conentrations of $400 \mathrm{pmol} / \mathrm{l},{ }^{10}$ comparable with the levels achieved in this study with PHI. The threshold molar concentrations for secretion of either peptide in man is not known though diarrhoea occurs with plasma concentrations in excess of $60 \mathrm{pmol} / 1$ in patients with vipomas. ${ }^{25}$ Formal dose response studies must be performed to fully address these questions.

The anatomical location of PHI to nerves of the submucosal region in the gut ${ }^{26}$ suggests that this peptide may subserve a neuroregulatory or neuromodulatory function. Its role in normal physiology and the possible relevance to human diarrhoeal disorders should now be investigated.

We are grateful to Sister Leela Francis-Reme and Mr James Barr for technical assistance, and Mrs Ann Corrigan for secretarial help.

\section{References}

1 Tatemoto K, Mutt V. Isolation of two novel candidate hormones using a chemical method for finding naturally occurring polypeptides. Nature $1980 ; 285$ : $417-8$.

2 Tatemoto K, Mutt V. Isolation of the intestinal peptide porcine PHI (PHI-27), a new member of the glucagonsecretin family. Proc Natl Acad Sci USA 1981; 78: 6603-7.

3 Dimaline R, Dockray G. Actions of a new peptide from porcine intestine ( $\mathrm{PHI})$ on pancreatic secretion in the rat and turkey. Life Sci 1980; 27: 1947-51.

4 Jensen RT, Tatemoto K, Mutt V, Lemp GF, Gardner JD. Actions of a newly isolated intestinal peptide PHI on pancreatic acini. Am J Physiol 1981; 241: G498-502.

5 Bataille D, Gespach C, Laburthe M, Amiranoff B, Tatemoto K, Vaculin N, Mutt V, Rosselin G. Porcine peptide having $\mathrm{N}$-terminal histidine and $\mathrm{C}$-terminal isoleucine amide (PHI). Vasoactive intestinal peptide (VIP) and secretin-like effects in different tissues from the rat. FEBS Lett 1980; 114: 240-2.

6 Lundberg JM, Tatemoto K. Vascular effects of the peptides PYY and PHI: comparison with APP and VIP. Eur J Pharmacol 1982; 83: 143-6.

7 Christofides ND, Yiangou Y, Aarons E et al. Radoimmunoassay and intramural distribution of PHI-IR in the human intestine. Dig Dis Sci 1984. (In press.)

8 Anagnostides AA, Manolas K, Christofides ND, Yiangou Y, Bloom SR, Chadwick VS. Peptide histidine isoleucine (PHI) induces secretion in the pig small intestine. [Abstract]. Gut 1982; 23: A898.

9 Ghiglione M, Christofides ND, Yiangou Y, Uttenthal LO, Bloom SR. PHI stimulates intestinal secretion. Neuropeptides 1982; 3: 121-5.

10 Krejs GJ, Fordtran JS. Effect of VIP infusion on water and ion transport in the human jejunum. Gastroenterology 1980; 78: 722-7.

11 Helma CA, Barbezat GO. The effect of gastric inhibitory polypeptide on human jejunal water and electrolyte transport. Gastroenterology 1977; 72: 37684.

12 Hicks T, Turnberg LA. The influence of secretin on ion transport in the human jejunum. Gut 1973; 14: 485-90.

13 Hicks T, Turnberg LA. Influence of glucagon on the human jejunum. Gastroenterology 1974; 67: 1148-58.

14 Moritz M, Finkelstein G, Meshkinpour H, Fingerut J, Lorber SH. Effect of secretin and cholecystokinin on the transport of electrolyte and water in human jejunum. Gastroenterology 1973; 64: 76-80.

15 Mekhjian H, King D, Sanzenbacher L, Zollinger R. 
Glucagon (GL) and secretin (SE) inhibit water and electrolyte transport in the human jejunum. Gastroenterology 1972; 62: 782.

16 Camilleri M, Cooper BT, Adrian TE, Bloom SR, Chadwick VS. Effects of vasoactive intestinal peptide and pancreatic polypeptide on rabbit intestine. Gut 1981; 22: 14-8.

17 Schwartz SE, Fitzgerald MA, Levine RA, Schwartzel EH. Intestinal cyclic nucleotides in "pancreatic cholera". Evidence against a second messenger role in intestinal secretion. Gastroenterology 1976; 70: 936.

18 Schwartz SE, Kimberg DV Sheerim HE, Field M, Said SI. Vasoactive intestinal peptide stimulation of adenylate cyclase and active electrolyte secretion in intestinal mucosa. J Clin Invest 1974; 54: 536-44.

19 Waldman BB, Gardner JD, Zfass AM, Makhlouf GM. Effects of vasoactive intestinal peptide, secretin and related peptides on rat colonic transport and adenylate cyclase activity. Gastroenterology 1977; 73: 518-23.

20 Simon B, Crygan P, Spaan G, Dietrich J, Kuther H. Hormone sensitive adenylate cyclase in human colonic mucosa. Digestion 1978; 17: 229-33.

21 Mailman D. Effects of VIP on intestinal absorption and blood flow. J Physiol 1978; 279: 121-32.

22 Krejs GJ, Barklet RM, Read NW, Fordtran JS. Intestinal secretion induced by VIP: A comparison with cholera toxin in canine jujunum in vivo. J Clin Invest 1978; 61: 1337-45.

23 Bloom SR, Polak JM, Pearse AGE. Vasoactive intestinal peptide and watery diarrhoea syndrome. Lancet 1973; 2: 14-6.

24 Rambaud JC, Modigliani R, Matuchansky C et al. Pancreatic cholera: studies on humoral secretions and pathophysiology of diarrhoea. Gastroenterology 1975; 69: 110-2.

25 Bloom SR. VIP and watery diarrhoea VI. In: Bloom SR, ed. Gut hormones. London: Churchill Livingstone, 1978: 583-8.

26 Christofides ND, Yiangou Y, Blank MA. Tatemoto K. Polak JM, Bloom SR. Are peptide histidine isoleucine and VIP co-synthesised in the same prohormones? Lancet 1982; 2: 1398. 